\title{
Origins and Development of Initiation of Free Radical Polymerization Processes
}

\author{
Dietrich Braun \\ Deutsches Kunststoff-Institut, Schlossgartenstr. 6, 64289 Darmstadt, Germany \\ Correspondence should be addressed to Dietrich Braun, dbraun@dki.tu-darmstadt.de
}

Received 10 June 2009; Accepted 26 October 2009

Recommended by Jose Ramon Leiza

\begin{abstract}
At present worldwide about $45 \%$ of the manufactured plastic materials and $40 \%$ of synthetic rubber are obtained by free radical polymerization processes. The first free radically synthesized polymers were produced between 1910 and 1930 by initiation with peroxy compounds. In the 1940s the polymerization by redox processes was found independently and simultaneously at IG Farben in Germany and ICI in Great Britain. In the 1950s the systematic investigation of azo compounds as free radical initiators followed. Compounds with labile C-C-bonds were investigated as initiators only in the period from the end of the 1960s until the early 1980 s. At about the same time, iniferters with cleavable S-S-bonds were studied in detail. Both these initiator classes can be designated as predecessors for "living" or controlled free radical polymerizations with nitroxyl-mediated polymerizations, reversible addition fragmentation chain transfer processes (RAFT), and atom transfer radical polymerizations (ATRP).
\end{abstract}

Copyright ( 2009 Dietrich Braun. This is an open access article distributed under the Creative Commons Attribution License, which permits unrestricted use, distribution, and reproduction in any medium, provided the original work is properly cited.

\section{Introduction}

Since the 1980 s about $50 \%$ of the total production of synthetic polymers worldwide used as plastics were obtained by free radical polymerization processes. Due to the increasing importance of metal organic initiation systems for plastics and synthetic rubber, the participation of radical polymerization is slightly decreasing, but nevertheless nowadays it still amounts annually to nearly $45 \%$ or about 100 million tons of plastic materials and $40 \%$ or 4.6 million tons of synthetic rubber.

In technical polymerization processes, peroxy compounds play since about 100 years the most important role beside about 60 years old redox systems and the azo initiators. Since about 30 years, the modern possibilities to control free radical polymerization reactions especially by suppressing termination and transfer processes attract increasing attention and technical interest, even if their share in the total polymer production is still rather small.

In most textbooks and monographs on free radical polymerization, only very few if at all is said on the history of this part of macromolecular chemistry. Therefore, the following review deals mainly with the development of initiation of free radical polymerization processes and the most important initiator classes. Due to the limitation to history of the initiating systems, the more recent developments in theory and details of the mechanisms and the kinetics of free radical polymerization processes will not be discussed.

\section{The Terms "Polymerization" and "Free Radicals"}

In 1832 the Swedish chemist Jöns Jacob Berzelius (17791848) recognized the existence of compounds with the same proportionate composition but different numbers of constituent atoms. He called this phenomenon "polymeric" (in German "Polymerie") (from the Greek $\pi \mathrm{o} \lambda \nu \mu \varepsilon \rho \eta \bar{\zeta}$, "consisting of many parts"). This term soon came in general use. So a chemical dictionary of the 1860 s offered the following, very modern sounding definition:

"Bodies are said to be polymeric when they have the same percentage composition, but different molecular weights; the olefins $\mathrm{C}^{n} \mathrm{H}^{2 n}$ for example."

Berthelot (1827-1907) called in a lecture at 27th of April 1863 in Paris the conversion reaction of certain compounds 
such as styrene to their polymerides "polymeric transformation" [1] (later commonly referred to as "polymerization").

Berthelot postulated that all substances, which can add hydrogen, chlorine or water, are able to polymerize and predicted that "incomplete" (in the present nomenclature "unsaturated") compounds should also be polymerizable. He discussed three possibilities to initiate such reactions.

(i) by direct application of heat; but he suspected also, that the evolution of heat due to reactions between the "monomer" molecules and the initiating species was the fundamental reason of polymerization.

(ii) by a simultaneous chemical reaction, what nowadays could be described as the formation of initiating species.

(iii) due to the influence of a "nascent" state according to Joseph Priestly (1733-1804), who applied this concept to an enhanced reactivity of hydrogen at the time of its release, which we now could call a reactive intermediate.

With these ideas, Berthelot can be considered the first "polymer chemist." He was an unusually creative scientist and published many papers on various fields of chemistry but also served in two French governments as Minister of Foreign Affairs (1895) and Minister of Education (1896/97).

The term "radical" was used since the middle of the 19th century for atoms or groups of several atoms, which up to day in many cases are considered constituents of chemical compounds.

As far back to the early days of the modern valence theory, organic chemists discussed the possible existence of free radical species and attempted to isolate them or at least their direct reaction products. In the 1850s, Charles Adolphe Wurtz proposed that the reaction of sodium with alkyl iodides (RI) produced compounds with empirical formulas corresponding to alkyl radicals $\left(\mathrm{R}^{\bullet}\right)$ :

$$
\begin{aligned}
& \mathrm{RI}+\mathrm{Na} \longrightarrow \mathrm{NaI}+\mathrm{R}^{\bullet} \\
& 2 \mathrm{R}^{\bullet} \longrightarrow \mathrm{R}-\mathrm{R}
\end{aligned}
$$

But in his experiments the obtained gases did not contain the free radicals but their dimers, as was deduced from their vapour densities.

In the following years with its success in explaining many of the known aspects of organic chemistry in terms of tetravalent carbon, little effort was made to isolate organic free radicals until the turn of the century. In 1900, Gomberg reported the existence of triphenylmethyl as the first stable radical, formally produced by the dissociation of "hexaphenylethane," which was prepared by the reaction of triphenylmethyl chloride either with silver or zinc dust:

$$
2\left(\mathrm{C}_{6} \mathrm{H}_{5}\right)_{3} \mathrm{C}-\mathrm{Cl} \longrightarrow 2\left(\mathrm{C}_{6} \mathrm{H}_{5}\right)_{3} \mathrm{C} \cdot \longrightarrow \text { Dimer }
$$

Since this invention, the existence of free radicals soon became a part of organic chemistry. However, it lasted almost about forty years before the importance of free radicals as species with unpaired electrons and as short-living reaction intermediates began to be fully accepted.

\section{Early History of the Theory of Free Radical Polymerization}

In 1920 Staudinger published his first paper "Über Polymerisation" [2] where he described the formation of long chain molecules by repeated addition of monomers and created the term "Makromoleküll." At this time the mechanism of such reactions was uncertain, but Staudinger proposed the participation of species with trivalent carbon atoms, which we now would call radicals. He also postulated [3], that the chain ends contain "free valences," which are unstable and grow until any at this time unknown kind of inactivation proceeds.

In a paper of 1929, Staudinger et al. [4] concluded that the polymerization is going on by an active state of the chains until the process is terminated by ring formation as at this time nothing was known about the chain length and the nature of the chain ends. In 1931 Staudinger and Kohlschütter [5] explained the polymerization of acrylic acid by an activation of the monomer molecule and a very fast addition of further monomer molecules in a chain reaction.

In 1935 Schulz suggested the activation of monomers for polymerization processes by "catalysts" [6]. In 1937 Flory described the kinetics of the vinyl polymerization as a chain reaction with participation of free radicals and postulated that two active (growing) chains can be terminated only by bimolecular combination or disproportionation reactions [7]. This paper of Flory can be considered the first complete formulation of the free radical polymerization, where the overall rate $R_{w}$ in dependence on concentrations of the monomer $[M]$ and the initiator $[I]$ can be described with the overall rate coefficient $K$ by the "square-root law": $R_{w}=$ $K \cdot[M] \cdot[I]^{1 / 2}$.

\section{Polymerization Processes before Hermann Staudinger}

Long before the initiation of polymerization processes by "catalysts" or initiators became known, some polymerizations initiated thermally or by light were described in the early literature. In all these cases it is not clear to which extent the presence of molecular oxygen took part in these reactions. Especially the so-called thermal polymerization of styrene and of some other vinyl monomers may at least have been partially initiated by primarily formed peroxides, as was suggested by Lautenschläger [8] already in 1913.

Probably the earliest description of a polymerization process was given by Simon [9] in 1839. He isolated styrene from storax, a liquid product from a plane tree (liquidamber orientalis) and observed that the liquid during storing became more and more viscous and finally a glass-like solid. He called the obtained resin "styroloxid," which a few years later by Blyth and Hofmann [10] was named "metastyrol," as it contained no oxygen. Interesting is also the remark of Hofmann and Blyth in 1845: "It is not unthinkable that metastyrol could be used for optical applications."

Blyth and Hofmann also observed that this metastyol was formed when styrene was exposed to sunlight, while it 
remained unchanged in the dark. According to Morawetz, [11] this is probably the first report on a light-induced polymerization. Another early example is the observation of Baumann in 1872, who described the transformation of vinyl chloride and vinyl bromide by sunlight to "isomeric bodies" [12].

Stobbe and Posnjak reported the first kinetic investigation of a vinyl polymerization in 1909 [13]. They studied the conversion of styrene to "metastyrol" by following the viscosity after heating at $200^{\circ} \mathrm{C}$ and found that freshly distilled styrene polymerized only after an induction period of seven hours, while no induction period was observed if the polymerization was started after a two weeks aging at room temperature before polymerization. This result was later confirmed by measurements of the refractive index to follow the reaction [14]. Stobbe and Posnjak concluded that in the aged styrene "a polymerization nucleus must have been formed which leads to the acceleration of the polymerization.” 1913 Lautenschläger suggested [8] in his much later [15] published dissertation that the observations of Stobbe and Posnjak should be explicable by the formation of small amounts of peroxides, which acted as polymerization catalysts.

\section{Most Important Initiator Classes for Free Radical Polymerization Reactions}

5.1. Peroxy Compounds. Besides the mentioned suggestion of Lautenschläger [8] on the action of peroxides in the styrene polymerization, it seems that Fritz Klatte at about 1912 for the first time used peroxy compounds to initiate the vinyl polymerization [16]. In 1913 in a patent "the preparation of horn substitute, artificial fibers, lacquers, and so forth. from poly(vinyl chloride)" was claimed. In a number of following inventions Klatte described the preparation of several monomers by the addition of inorganic acids like hydrogen chloride and a number of organic acids like chloroacetic acid to acetylene using mercury catalysts and their polymerization by heat or light "with and without additives." In one of his patents [17], he mentioned the remarkable acceleration of the polymerization by so-called catalysts like peroxides, ozonides, or oxygen forming products like perborates or percarbonates. But he also realized that the formation of peroxides from the used monomers can initiate polymerization processes similar to that with benzoyl peroxide. He also found that copper or copper compounds can inhibit the polymerization.

But it lasted many years until the generation of free radicals from peroxides was generally accepted as a method for initiation of polymerizations. Even in a review of 1937, [18] this was considered controversial, and in many papers rather vague formulations like "activation of monomers" (e.g., Schulz in 1937 [19]) were used. But-as already mentioned-in the same year Flory had no doubt that free radicals at the end of the growing polymer chains were responsible for the chain propagation and he gave the first description of the mechanism and the kinetics of the free radical polymerization of vinyl compounds as a chain reaction.
In the 1940s Price and Tate [20], Nozaki and Bartlett [21], Kern and Kämmerer [22] and others, and some years later Bevington et al. $[23,24]$ reported that initiator fragments from peroxides were attached to each polymer chain. For these investigations, peroxides with chemically (e.g., with bromine atoms), spectroscopically (e.g., with azo groups or IR sensitive structural units) or ${ }^{14} \mathrm{C}$-labeled peroxides were used, which are also early examples for end group analyses for molecular weight determination of vinyl polymers. Kern summarized these results in 1947/48 [25] and formulated the primary step of free radical polymerizations by peroxides with substituents X:

$$
\begin{aligned}
& \mathrm{X}-\mathrm{Ph}-\mathrm{CO}-\mathrm{O}-\mathrm{O}-\mathrm{CO}-\mathrm{Ph}-\mathrm{X} \longrightarrow 2 \mathrm{X}-\mathrm{Ph}-\mathrm{CO}-\mathrm{O}^{\cdot} \\
& \mathrm{X}-\mathrm{Ph}-\mathrm{CO}-\mathrm{O}^{*}+\mathrm{CH}_{2}=\mathrm{CHR} \longrightarrow \mathrm{X}-\mathrm{Ph}-\mathrm{CO}-\mathrm{O}-\mathrm{CH}_{2} \mathrm{CHR} \cdot
\end{aligned}
$$

Besides the so-obtained ester end groups especially at higher polymerization temperatures the benzoxy radicals can decarboxylate to $\mathrm{X}$-Ph $\bullet$-radicals which contrary to the ester groups are not cleavable by acids or alkali. This can be used to determine the degree of decarboxylation during the initiation step.

5.2. Redox Systems. Long before the explanation of the free radical polymerization by its various steps like initiation, propagation, and termination, the retardation of the polymerization of unsaturated compounds and the acceleration of polymerization by molecular oxygen were observed. These phenomena were explained by the formation of polymeric peroxides and their thermal cleavage to free radicals. The first idea was that such polymeric peroxides decompose under formation of "active" oxygen, which could initiate the polymerization, whereas molecular oxygen would inhibit the polymerization. So in the beginning of these investigations, it was uncertain why oxygen under some conditions accelerates the polymerization and under others acts as an inhibitor. Later this effect was understood as a competition between autoxidation and inhibition [26].

From experiments to suppress the inhibition of polymerization processes by molecular oxygen resulted one of the technically most important method of initiation of polymerization, originally called redox catalysis. Of large importance in this respect was the observation of Winnacker and Patat that the reproducibility of the emulsion polymerization of chloroprene in presence of oxygen in alkaline medium can be improved by adding reduction agents like sulfites or hyposulfites, which remarkably increased the polymerisation rate [27].

On the basis of these observations in the German laboratories of IG Farben in Höchst and Leverkusen it was soon realized that this effect was caused by the reaction of reducing and oxidating reagents, that is, by a redox process. Kern finally explained the primary step of such redox polymerizations by the formation of free radicals from peroxides and ferrous ions [28]: 


$$
\begin{gathered}
\mathrm{Y}-\mathrm{CO}-\mathrm{O}-\mathrm{O}-\mathrm{CO}-\mathrm{Y}+\mathrm{Fe}^{2+} \longrightarrow \mathrm{Y}-\mathrm{CO}-\mathrm{O} \cdot+\mathrm{Y}-\mathrm{CO}-\mathrm{O}^{-}+\mathrm{Fe}^{3+} \\
\mathrm{Y}-\mathrm{CO}-\mathrm{O}^{*}+\mathrm{CH}_{2}=\mathrm{CHR} \longrightarrow \mathrm{Y}-\mathrm{CO}-\mathrm{O}-\mathrm{CH}_{2} \mathrm{CHR}^{\cdot}
\end{gathered}
$$

Later on it was observed that this type of reaction could also be extended to combinations of many nonperoxidic oxidating agents with organic reducing compounds.

As a result of the Yalta agreement between the Allied Powers, after the Second World War Germany was not permitted to continue these research activities, which were of high interest for the production of synthetic rubber. Therefore the cold rubber technology on the basis of redox systems was developed in the United States, where in 1954 about $70 \%$ of the total synthetic rubber was produced by this method.

In September 1945 the Faraday Society organized a "General Discussion on Oxidation" with a section on electron transfer reactions. At this meeting Bacon reported on extensive studies of redox-initiated polymerizations that had been carried out since October 1940 in the laboratories of Imperial Chemical Industries [29, 30]. From Evans' laboratory followed an account of the study of vinyl polymerization in aqueous solution by hydrogen peroxide and ferrous ions [31]:

$$
\begin{gathered}
\mathrm{H}_{2} \mathrm{O}_{2}+\mathrm{Fe}^{2+} \longrightarrow \mathrm{HO} \cdot+\mathrm{Fe}^{3+}+\mathrm{HO}^{-} \\
\mathrm{HO} \cdot+\mathrm{CH}_{2}=\mathrm{CHR} \longrightarrow \mathrm{HO}-\mathrm{CH}_{2}-\mathrm{CHR} \cdot \longrightarrow \text { Polymer }
\end{gathered}
$$

Similarly, polymerization was induced by the reaction of a reducing agent to a persulfat containing solution. So the redox polymerization has two independent roots, as due to the war none of the participating groups was aware of the work carried out in the other country.

5.3. Azo Compounds. The use of triphenyl azobenzene by Schulz in 1939 drew first attention to azo compounds as polymerization initiators [32]:

$$
\left(\mathrm{C}_{6} \mathrm{H}_{5}\right)_{3} \mathrm{C}-\mathrm{N}=\mathrm{N}-\mathrm{C}_{6} \mathrm{H}_{5}
$$

Gomberg obtained this azo compound in 1897 [33]. The first and up to now mostly used aliphatic azo initiator azoisobutyronitrile (AIBN) was discovered by Thiele and Heuser in 1896 [34]. The observation that AIBN yields initiating radicals at the same rate in a variety of solvents by several authors $[35,36]$ made AIBN the initiator of choice in kinetic studies of free radical polymerizations. But only in the early 1950s the systematic investigation of this initiator class started, and now in the Polymer Handbook about 300 suitable aliphatic azo initiators are summarized. Most of them are easily obtained by adding HCN to ketones followed by reaction with hydrazine und oxidation with, for example, bromine.

$$
\text { AIBN } \quad \begin{array}{ccc}
\left.\mathrm{CH}_{3}\right)_{2} \mathrm{C}-\mathrm{N}=\mathrm{N} & \mathrm{N}-\underset{\mid}{\mathrm{C}}\left(\mathrm{CH}_{3}\right)_{2} \\
& \stackrel{\mathrm{CN}}{\mathrm{CN}} &
\end{array}
$$

One of the problems of this type of azo compounds is their content of cyano groups, which may cause toxic side products during their thermal decomposition.
Therefore later several nitrile free azo compounds were synthesized and used as initiators, for example, azo esters [37-39]:

$$
\begin{gathered}
\mathrm{C}_{6} \mathrm{H}_{5} \mathrm{R}^{1} \mathrm{R}^{2} \mathrm{C}-\mathrm{N}=\mathrm{N}-\mathrm{CR}^{2} \mathrm{R}^{1} \mathrm{C}_{6} \mathrm{H}_{5} \\
\text { With } \mathrm{R}^{1}=\text { alkyl, } \mathrm{R}^{2}=\text { OOC-alkyl }
\end{gathered}
$$

Some other azo initiators with functional groups like carboxy create reactive end groups on the produced polymer chains for further modification, for example, for the synthesis of block copolymers.

Till now, there is not enough information available about the theoretical relationships between chemical structure and decomposition behaviour but nevertheless, nowadays a broad variety of azo initiators for a large range of polymerization temperatures is available.

5.4. Initiators with Labile $C-C$-Bonds. Since many years it is known that the strength of C-C-bonds and the stability of the radicals formed by homolytic thermal cleavage of such bonds depend mainly on the kind and size of the substituents on these carbon atoms. For example, tetraphenylsuccinic acid dinitrile $(\mathrm{X}=\mathrm{CN}$ in the general formula below) is cleaved at $100^{\circ} \mathrm{C}$ in solution into diphenylmethyl cyanomethyl radicals. Even as the degree of dissociation is small, these radicals are sufficiently reactive to initiate the polymerization of styrene, as was described by Schulz and Wittig already in 1939 [40].

These investigations did not find scientific or practical interest, probably due to the much easier available peroxides. Much later, in 1969, another example for the initiation of free radical polymerizations by $\mathrm{C}-\mathrm{C}$-cleavage was found by chance by Braun and Becker $[41,42]$. They observed, that benzopinacol $(\mathrm{X}=\mathrm{OH})$ by thermal treatment yields radicals that are able to initiate the polymerization of vinyl monomers, but not the initially produced diphenyl hydroxy methyl radicals are the initiating species; these radicals transfer hydrogen atoms to the monomer under initiation of a growing chain and formation of benzophenone (Scheme 1). The authors called that process transfer initiation.

Continuing these observations, in 1981 Bledzki and Braun [43] and Braun [44] investigated this until that time not noted initiator class of tetraaryl-substituted alkanes with various constituents X (see Scheme 2) in more detail.

They found that by thermal cleavage of tetraaryl ethanes with $\mathrm{X}=\mathrm{CN}$, OR, but also with halogen or alkyl groups substituted diaryl methyl radicals cannot only initiate the vinyl polymerization but also cause rather strong primary radical termination.

The by primary radical termination resulting and due to the large and-depending on the structure of the last monomer unit-thermally labile end groups can undergo reversible cleavage at the chain ends. Therefore the so obtained polymers consist of "dormant" macromolecules 


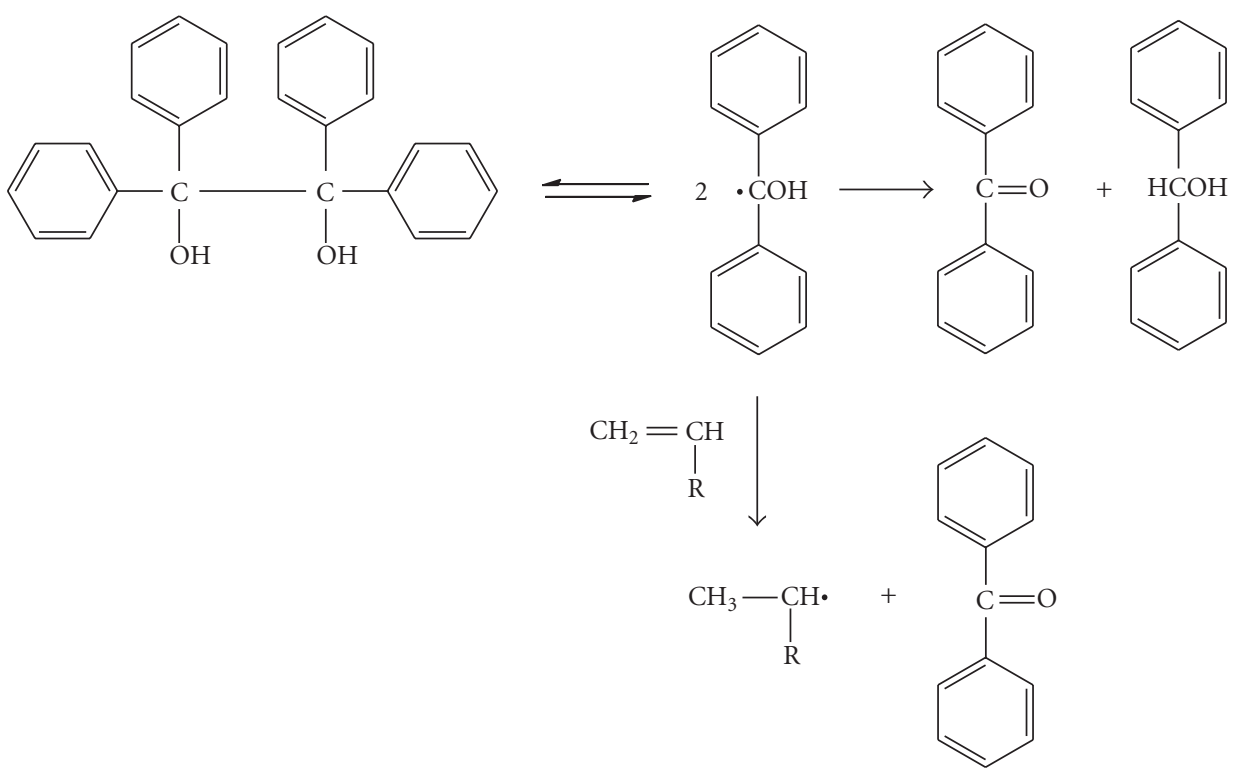

Scheme 1: Thermal decomposition of benzopinacol and initiation of vinyl polymerization by the formed diphenyl hydroxy methyl radicals.

$$
\begin{aligned}
& \begin{aligned}
\left(\mathrm{C}_{6} \mathrm{H}_{5}\right)_{2} \mathrm{C} & \underset{\mid}{\mathrm{C}}-\underset{\mathrm{X}}{\mathrm{C}}\left(\mathrm{C}_{6} \mathrm{H}_{5}\right)_{2} \\
\mathrm{X} & \quad \mathrm{X}
\end{aligned} \\
& \mathrm{X}=\mathrm{OH}, \mathrm{OCH}_{3}, \mathrm{O}-\mathrm{C}_{6} \mathrm{H}_{5}, \mathrm{CN}, \mathrm{CH}_{3}, \mathrm{O}-\mathrm{Si}\left(\mathrm{CH}_{3}\right)_{3}
\end{aligned}
$$

Scheme 2: Tetraalkyl-substituted alkanes with constituents X.

that can reinitiate the polymerization reaction and are in this respect a predecessor of the later, called living or controlled free radical polymerization, as shown in the example with tetraphenyl succinic acid dinitrile in Scheme 3.

Due to this "stepwise" addition of monomer molecules the degree of polymerization increases with increasing conversion, as is shown in Figure 1 for the bulk polymerization of methyl methacrylate with 1.2-diphenoxy-1.1.2.2tetraphenyl ethane.

At about the same time Otsu and Yoshida [45] investigated initiators with labile $-\mathrm{S}_{-} \mathrm{S}_{-},-\mathrm{CO}-\mathrm{S}_{-},-\mathrm{CS}-\mathrm{S}-$, and
-O-CS-S- bonds like diaryl disulfides, dibenzoyl disulfide, tetraalkyldithiuram disulfides, and (bisalkylxanthogen) disulfides, for example,

$$
\begin{array}{rl}
\mathrm{Ph}-\mathrm{S}-\mathrm{S}-\mathrm{Ph} & \mathrm{Ph}-\mathrm{CO}-\mathrm{S}-\mathrm{S}-\mathrm{CO}-\mathrm{Ph} \\
(\text { alkyl })_{2} \mathrm{~N}-\mathrm{CS}-\mathrm{S}-\mathrm{S}-\mathrm{CS}-\mathrm{N}(\text { alkyl })_{2} & \text { alkyl-O-CS-S-S-CS-O-alkyl }
\end{array}
$$

Such compounds may be decomposed thermally or photochemically to initiating radicals, but the chain transfer to the initiator is the most important mechanism for the termination of growing polymer chains. In most cases the obtained endgroups are thermally stable, but photochemically labile, which can be described as a photoinitiated living polymerization.

General scheme of the polymerization of monomer M by disulfides with substituents R:

$$
\begin{aligned}
\mathrm{R}-\mathrm{S}-\mathrm{S}-\mathrm{R} & \longrightarrow 2 \mathrm{R}-\mathrm{S}^{\cdot} \\
\mathrm{R}-\mathrm{S}^{*}+n \mathrm{M} & \longrightarrow \mathrm{Pol} \cdot \\
\mathrm{R}-\mathrm{S}-\mathrm{S}-\mathrm{R}+\mathrm{Pol} \cdot & \longrightarrow \mathrm{Pol}-\mathrm{SR}+\mathrm{R}-\mathrm{S}^{\cdot} \\
\mathrm{Pol} \cdot+\mathrm{R}-\mathrm{S}^{\cdot} & \longrightarrow \text { Pol-SR }
\end{aligned}
$$

Otsu named such initiators that at the same time are starters, chain transfer agents, and terminators "iniferters (initiator, transfer agent, chain terminator) or initers (initiator, chain terminator), in analogy to the similar terminology used by Kennedy [46] for cationic systems.

5.5. Controlled Free Radical Polymerization. The usual free radical polymerization is determined by chain termination and chain transfer processes which limit the length of growing chains and are the reason for normally rather broad molecular weight distributions. Therefore, many researchers looked for radical processes, where these irreversible terminating steps are avoided or at least strongly restricted, similar to the so called anionic "living polymerization," which term was introduced in 1956 by Szarwc et al. $[47,48]$ for the anionic polymerization of styrene in aprotic solvents. The 

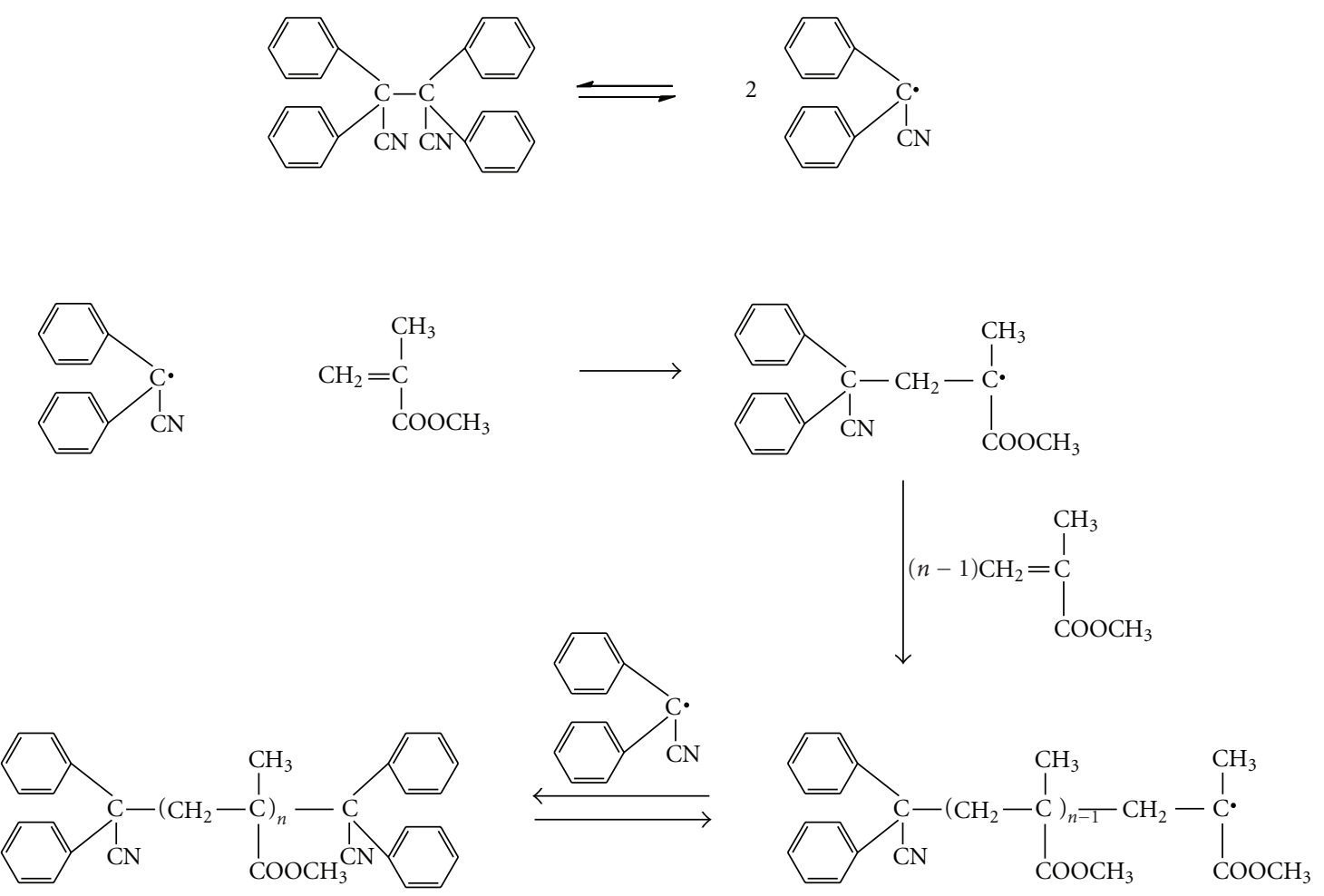

Scheme 3: Polymerization of methyl methacrylate with succinic acid dinitrile.

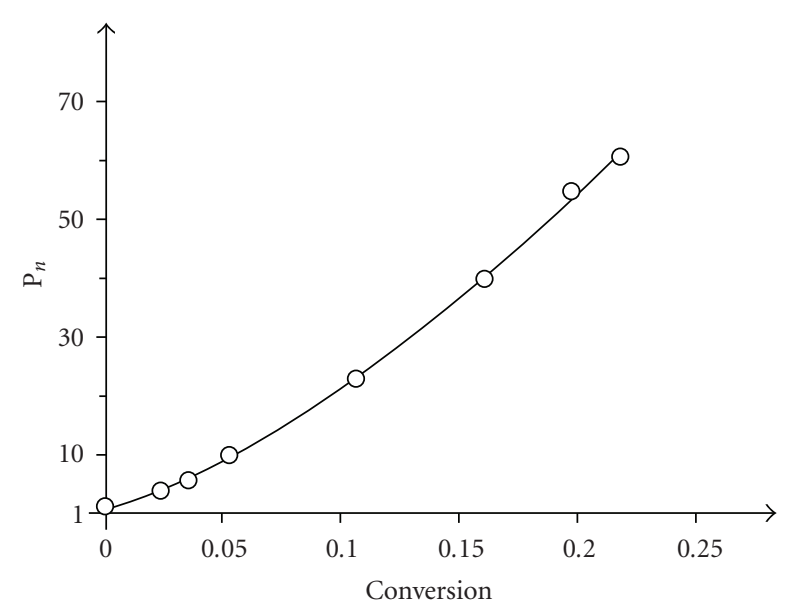

FIGURE 1: Bulk polymerization of methyl methacrylate with 1.2diphenoxy-1.1.2.2-tetraphenylethane $\left(30 \mathrm{mmol} . \mathrm{l}^{-1}\right)$ at $\left.70^{\circ} \mathrm{C}\right)$; (data from [43]).

task was to minimize the rate of reactions between the radical species themselves (termination and chain transfer) and to convert reactive growing species reversibly into dormant species.

One of the first examples are the polymerizations that were initiated with highly substituted alkanes (see above). Here the initiating radicals are also chain-terminating agents. The relatively weak bond between the last monomer unit and the terminating radical opens the chance of reactivating the chains, which insofar can be named "dormant." With tetraaryl alkanes due to the relatively frequent terminating steps the obtainable degrees of polymerization are rather small and the molecular weight distributions are not very narrow.

Therefore, the controlling effect in this type of "living" polymerization is rather limited, but these initiators fulfil the principle requirements for controlling the radical polymerization.

(i) The radicals formed by initiator decomposition must be relatively long living and they can initiate the polymerization with rather slow rates.

(ii) Primary radical termination and/or chain transfer to the initiator should be the only or at least main mechanism for interruption of the chain growth.

(iii) The bond of the initiator fragment to the chain end must be thermally or photochemically labile.

The following Scheme 4 shows the principle of living free radical polymerization processes with $\mathrm{I}-\mathrm{X}$ as the initiating species in a dynamic equilibrium with a relatively small number of growing free radicals and a large number of deactivated "dorming" species [49]. In such reactions irreversible chain transfer and chain termination are not completely impossible but pushed back to a high degree.

The actual investigations on living free radical polymerizations are characterized by a lot of systems where the growing chain adds more or less stable free radicals that terminate the chains by forming of relatively weak bonds that can be cleaved again thermally or photochemically. 


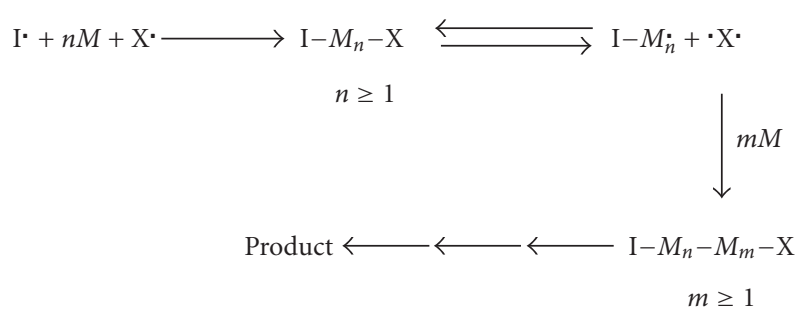

Scheme 4: Living free radical polymerization with I-X as the initiating species.

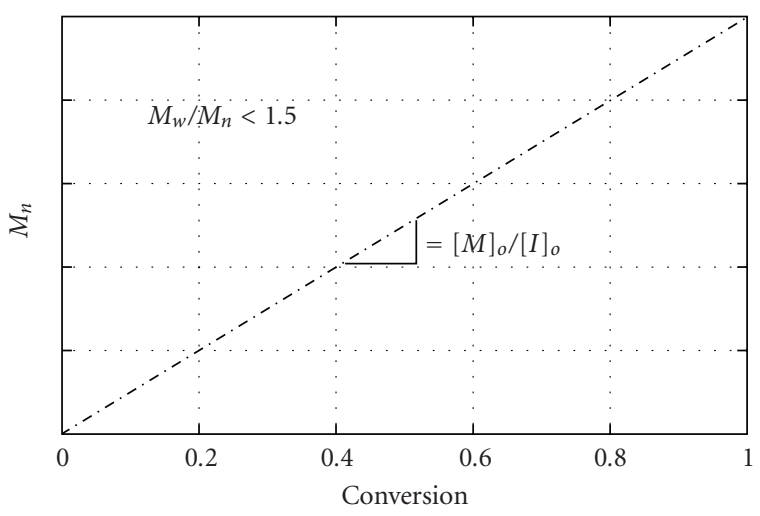

FIgURE 2: Relationship between molecular weight and conversion in the ideal free radical living polymerization.
An interesting reaction of this type is the nitroxylmediated polymerization, invented by Solomon and Rizzardo in the middle of the 1980s [50]. The reaction is initiated by classical radical initiators like peroxides or azo compounds. The termination of the growing chains by nitroxyls like 2.2.6.6-tetramethylpiperidine-1-oxyl (TEMPO) yields $\mathrm{C}-\mathrm{ON}$-bonds at the chain ends which are reversibly cleavable with the rate constants $k_{a}$ and $k_{d}$ above $100^{\circ} \mathrm{C}\left(k_{p}\right.$ : rate constant for chain propagation):

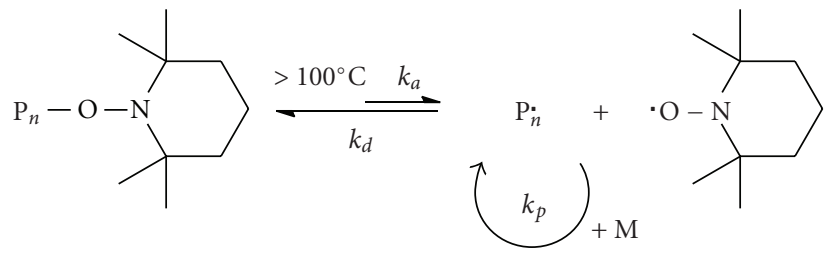

But in principle, this method is connected-not to the same extent-with similar problems like the polymerization by substituted tetraarylalkanes (see above).

Another possibility for controlling the free radical polymerization by "Reversible Addition Fragmentation Chain Transfer" (RAFT) was invented by Krstina et al. in 1995 [51]. In this case the polymerization is initiated with small concentrations of usual initiators. The growing chain $\left(\mathrm{P}_{n} \bullet\right)$ reacts with substituted dithioesters by a "radical transesterification" to an equilibrium between active and deactivated species:

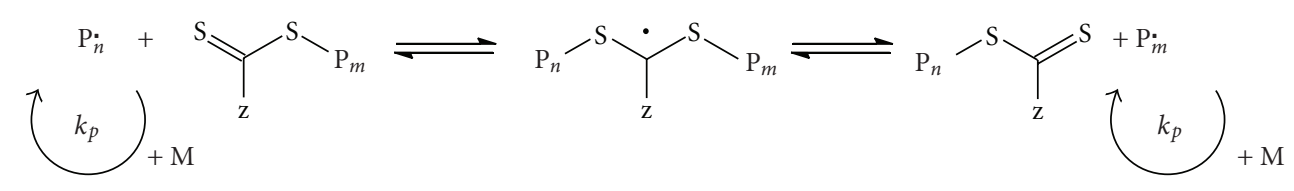

But most interest during the recent years got the "Atom Transfer Radical Polymerization" (ATRP), described by Matyjaszewski et al. $[52,53]$ as a catalytic process, where the proportion of radicals (or the polymerization rate) can be easily controlled by the amount and the activity of the catalyst. It is a repetitive addition of a monomer to growing radicals generated from "dormant" alkyl halides (R-X) by a reversible redox process catalyzed by transition metal compounds, such as cuprous halides complexed, for example, by two $2,2^{\prime}$-bipyridine (bipy) molecules:

$$
\mathrm{P}_{n}-\mathrm{X}+\mathrm{Cu}(\mathrm{I}) / 2 \text { bipy } \longleftarrow \longrightarrow \mathrm{P}_{n}^{*}+\mathrm{X}-\mathrm{Cu}(\mathrm{II}) / 2 \text { bipy }
$$

In the initiation step radicals are formed from alkyl halides R$\mathrm{X}$ by a reversible redox process with a transition metal halide like cuprous chloride:

$$
\mathrm{R}-\mathrm{X}+\mathrm{Cu}(\mathrm{I}) \mathrm{X} \quad \longleftrightarrow \quad \mathrm{R} \cdot+\mathrm{Cu}(\mathrm{II}) \mathrm{X}_{2}
$$

Due to a dynamic equilibrium between dorming $\left(\mathrm{P}_{n}-\mathrm{X}\right)$ and active $\left(\mathrm{P}_{n}^{*}\right)$ polymer chains the concentration of active species is very small. The radicals add monomer molecules to growing polymer chains that were reversibly terminated by halide addition from the $\mathrm{Cu}$ (II) halide:

$$
\mathrm{P}_{n}+\mathrm{Cu}(\mathrm{II}) \mathrm{X}_{2} \longleftrightarrow \mathrm{P}_{n} \mathrm{X}+\mathrm{Cu}(\mathrm{I}) \mathrm{X}
$$

The process is terminated as in the conventional radical polymerization by combination or disproportionation of two active growing chains, but due to the small concentration of active polymer chains only a small degree of these chains is irreversibly terminated. The molecular weight of the polymer can be determined by the ratio of used monomer to initiator concentration: $\mathrm{P}_{n}=\Delta[M] /[I]_{0}$. The so obtainable polydispersity $M_{w} / M_{n}$ is between 1.0 and 1.5 .

With suitable catalysts (metal salt and ligand) and initators in the ideal case the molecular weight increases as typical for living polymerizations linearly with the conversion (Figure 2).

The task of the ligand is to dissolve the metal salt in organic solvents and to control the redox potential of the metal with respect to reactivity [54]. For this purpose a large number of ligands were investigated, as the examples of nitrogen containing ligands for the ATPR with copper catalyst show (Scheme 5). 


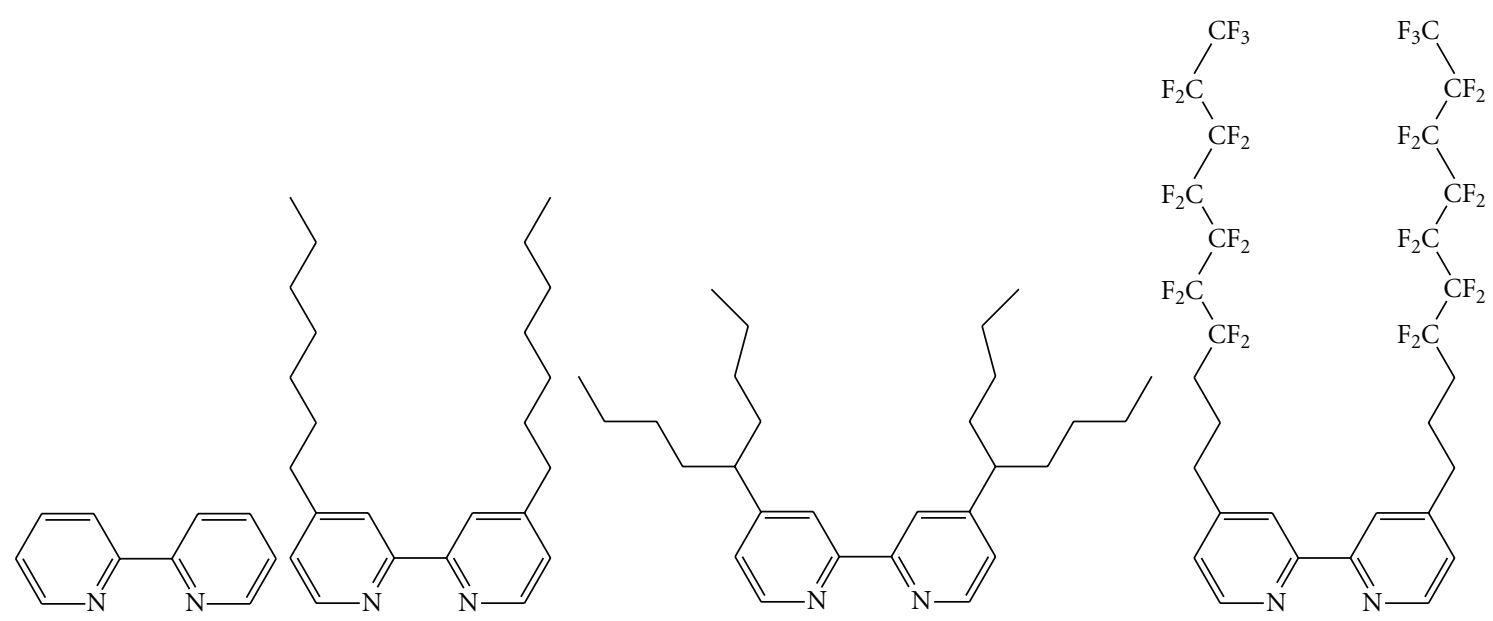<smiles>[R]c1ccnc(-c2cc([R])cc(-c3cc([R])ccn3)n2)c1</smiles><smiles></smiles>

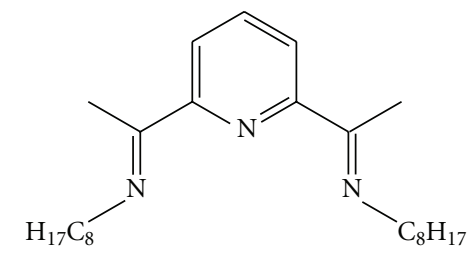

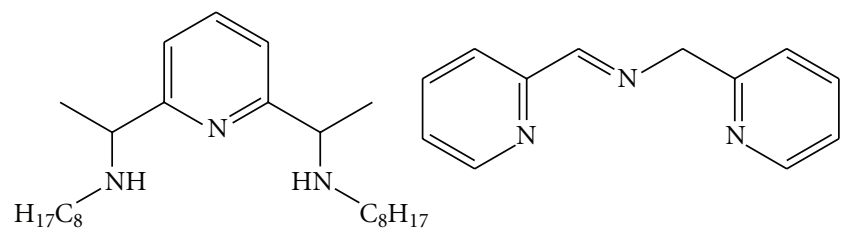<smiles>c1ccc(CN(Cc2ccccn2)Cc2ccccn2)nc1</smiles><smiles>CCCCCCCCCN(C)CCN(C)C</smiles>

Scheme 5: Nitrogen ligands for the ATPR with copper catalysts.

By using alkyl halides with functional groups as initiators it is possible to create functional end groups at the polymer chains, which can be used to synthesize block, star, or graft copolymers in subsequent reactions. Some for such purposes suited initiators can be seen in Scheme 6.

The investigation of free radical polymerizations that are completely or at least to a large extend without any termination steps is presently one of the most actual fields of free radical polymerization, even if the discussion on the nomenclature of such processes ("living" or "controlled") is by no means finished $[55,56]$.

This report on the history of initiation of polymerization processes by the presently most important classes of free radicals demonstrates that these reactions concern by no 
<smiles>Cc1ccc(CBr)cc1</smiles><smiles>BrCc1ccc(Br)cc1</smiles><smiles>N#Cc1ccc(CBr)cc1</smiles><smiles>CC(Br)C(=O)OC(C)(C)C</smiles><smiles>CC(Br)C(=O)OCC1CO1</smiles><smiles>CC(Br)C(=O)OCCO</smiles><smiles>CC(Br)C#N</smiles><smiles>NC(=O)CCl</smiles><smiles>O=C1OCCC1Br</smiles><smiles>C=COC(=O)CCl</smiles>

Scheme 6: Alkyl halides as initiators for ATPR.

means a "ripe" field of polymer science. In spite of its chain reaction character with extremely fast steps it is now possible to control and to tailor the free radical polymerization by methods which were unthinkable in its beginning more than 80 years ago. It can be expected that in the near future the further development of the controlled free radical polymerization will find increasing practical application.

\section{Acknowledgment}

The author thanks the Dr. Illing Stiftung für Makromolekulare und Technische Chemie for the generous support of his research on free radical polymerization.

\section{References}

[1] M. Berthelot, Lecons de Chimie Professées en 1864 et 1865, Société de Paris, Paris, France, 1866.

[2] H. Staudinger, "Über Polymerisation," Berichte der Deutschen Chemischen Gesellschaft, vol. 53, no. 6, pp. 1073-1085, 1920.

[3] H. Staudinger, "Die Chemie der hochmolekularen organischen Stoffe im Sinne der Kekuléschen Strukturlehre," Berichte der Deutschen Chemischen Gesellschaft, vol. 59, pp. 3019-3043, 1926.

[4] H. Staudinger, M. Brunner, K. Frey, P. Garbsch, R. Signer, and S. Wehrli, "Über das Polystyrol, ein Modell des Kautschuks," Berichte der Deutschen Chemischen Gesellschaft, vol. 62, no. 1, pp. 241-263, 1929.

[5] H. Staudinger and H. W. Kohlschütter, Berichte der Deutschen Chemischen Gesellschaft, vol. 64, p. 2019, 1931.

[6] G. V. Schulz, "On the relationship between the rate of reaction and composition of the reaction products in macro polymerisation processes," Zeitschrift für Physikalische Chemie, vol. 30, p. 379, 1935.

[7] P. J. Flory, "The mechanism of vinyl polymerizations," Journal of the American Chemical Society, vol. 59, no. 2, pp. 241-253, 1937.

[8] L. Lautenschläger, Ph.D. thesis, University of Karlsruhe, Karlsruhe, Germany, 1913.

[9] E. Simon, Justus Liebigs Annalen der Chemie, vol. 31, p. 267, 1839.

[10] J. Blyth and A. W. Hofmann, "Ueber das Styrol und einige seiner Zersetzungsprodukte," Justus Liebigs Annalen der Chemie, vol. 53, no. 3, pp. 289-329, 1845.
[11] H. Morawetz, in Polymers: The Origins and Growth of a Science, p. 17, John Wiley \& Sons, New York, NY, USA, 1985.

[12] E. Baumann, "Ueber einige Vinylverbindungen," Justus Liebigs Annalen der Chemie, vol. 163, no. 3, pp. 308-322, 1872.

[13] H. Stobbe and G. Posnjak, Justus Liebigs Annalen der Chemie, vol. 371, no. 3, p. 259, 1909.

[14] H. Stobbe, "Polymerisation des Styrols," Justus Liebigs Annalen der Chemie, vol. 409, no. 1, pp. 1-13, 1915.

[15] H. Staudinger and L. Lautenschläger, "Über Polymerisation und Autoxydation," Justus Liebigs Annalen der Chemie, vol. 488, no. 1, pp. 1-8, 1931.

[16] M. Kaufman, The History of PVC, chapter 2, Maclaren and Sons, Glasgow, Scotland, 1969.

[17] DRP, 281 688, Griesheim-Elektron, 1913.

[18] D. H. Hey and W. A. Waters, "Some organic reactions involving the occurrence of free radicals in solution," Chemical Reviews, vol. 21, no. 1, pp. 169-208, 1937.

[19] G. V. Schulz, "On the relationship between the rate of reaction and composition of the reaction products in macro polymerisation processes," Zeitschrift für Physikalische Chemie, vol. 30, p. 379, 1935.

[20] C. C. Price and B. E. Tate, "The polymerization of styrene in the presence of 3,4,5-tribromobenzoyl peroxide," Journal of the American Chemical Society, vol. 65, no. 4, pp. 517-520, 1943.

[21] K. Nozaki and P. D. Bartlett, "The kinetics of decomposition of benzoyl peroxide in solvents. I," Journal of the American Chemical Society, vol. 68, no. 9, pp. 1686-1692, 1946.

[22] W. Kern and H. Kämmerer, "Die chemische Molekulargewichtsbestimmung von Polystyrolen, II," Journal für Praktische Chemie, vol. 161, no. 11-12, pp. 289-292, 1943.

[23] J. C. Bevington, H. W. Melville, and R. P. Taylor, "The termination reaction in radical polymerizations. Polymerizations of methyl methacrylate and styrene at $25^{\circ}$," Journal of Polymer Science, vol. 12, no. 1, pp. 449-459, 1954.

[24] J. C. Bevington, H. W. Melville, and R. P. Taylor, "The termination reaction in radical polymerizations. II. Polymerizations of styrene at $60^{\circ}$ and of methyl methacrylate at 0 and $60^{\circ}$, and the copolymerization of these monomers at $60^{\circ}$," Journal of Polymer Science, vol. 14, no. 77, pp. 463-476, 1954.

[25] W. Kern, "Über den Primärakt der mit Hilfe von Peroxyden ausgelösten Polymerisation ungesättigter Verbindungen,” Die Makromolekulare Chemie, vol. 1, no. 3, pp. 229-248, 1948.

[26] W. Kern, "Über den Einfluß des molekularen Sauerstoffes auf die Polymerisation ungesättigter Verbindungen," Die Makromolekulare Chemie, vol. 1, no. 3, pp. 199-208, 1948. 
[27] W. Kern, "Die Katalyse der Polymerisation ungesättigter Verbindungen mit Hilfe von Redoxsystemen," Die Makromolekulare Chemie, vol. 1, no. 3, pp. 209-228, 1948.

[28] W. Kern, "Die Metallredoxkatalyse der Polymerisation ungesättigter Verbindungen,” Die Makromolekulare Chemie, vol. 1, no. 3, pp. 249-268, 1948.

[29] R. G. R. Bacon, "Reduction activation. A new polymerisation technique," Transactions of the Faraday Society, vol. 42, pp. 140-155, 1946.

[30] R. G. R. Bacon, "The initiation of polymerisation processes by redox catalysts,” Quarterly Reviews, vol. 9, no. 3, pp. 287-310, 1955.

[31] J. H. Baxendale, M. G. Evans, and C. S. Park, "The mechanism and kinetics of the initiation of polymerisation by systems containing hydrogen peroxide," Transactions of the Faraday Society, vol. 42, pp. 155-169, 1946.

[32] G. V. Schulz, "Anregung von Kettenpolymerisationen durch freie Radikale: II. Entwicklung der Radikale durch Zersetzung einer Azoverbindung," Die Naturwissenschaften, vol. 27, no. 39, pp. 659-660, 1939.

[33] M. Gomberg, "Tetraphenylmethan," Berichte der Deutschen Chemischen Gesellschaft, vol. 30, no. 2, pp. 2043-2047, 1897.

[34] J. Thiele and K. Heuser, "Ueber Hydrazinderivate der Isobuttersäure," Justus Liebigs Annalen der Chemie, vol. 290, no. 1, pp. 1-43, 1896.

[35] F. M. Lewis and M. S. Matheson, "Decomposition of aliphatic azo compounds," Journal of the American Chemical Society, vol. 71, no. 2, pp. 747-748, 1949.

[36] C. G. Overberger, M. T. O’Shaughnessy, and H. Shalit, "The preparation of some aliphatic azo nitriles and their decomposition in solution," Journal of the American Chemical Society, vol. 71, no. 8, pp. 2661-2666, 1949.

[37] D. Braun and R. Jakobi, "Synthesis and decomposition of azoinitiators, I," Monatshefte für Chemie, vol. 113, no. 12, pp. 1403-1414, 1982.

[38] D. Braun and R. Jakobi, "Synthese und Zerfall von Azoinitiatoren, II," Monatshefte für Chemie, vol. 114, no. 1, pp. 37-45, 1983.

[39] D. Braun and R. Jakobi, "Neue Initiatoren zur Polymerisationsauslösung," Die Angewandte Makromolekulare Chemie, vol. 105, no. 1, pp. 217-230, 1982.

[40] G. V. Schulz and G. Wittig, "Anregung von Kettenpolymerisationen durch freie Radikale," Naturwissenschaften, vol. 27, no. 22, pp. 387-388, 1939.

[41] D. Braun and K. H. Becker, "Aromatische Pinakole als Polymerisationsinitiatoren," Die Angewandte Makromolekulare Chemie, vol. 6, no. 1, pp. 186-189, 1969.

[42] D. Braun and K. H. Becker, "Kinetik der Polymerisationsauslösung mit aromatischen Pinakolen," Die Makromolekulare Chemie, vol. 147, no. 1, pp. 91-99, 1971.

[43] A. Bledzki and D. Braun, "Polymerisationsauslösung mit substituierten Ethanen, 1. Polymerisation von Methylmethacrylat mit 1,1,2,2-Tetraphenyl-1,2-diphenoxyethan," Makromolekulare Chemie, vol. 182, no. 4, pp. 1047-1056, 1981.

[44] D. Braun, "Initiation of free radical polymerization by thermal cleavage of carbon-carbon bonds," Macromolecular Symposia, vol. 111, pp. 63-71, 1996.

[45] T. Otsu and M. Yoshida, "Role of initiator-transfer agentterminator (iniferter) in radical polymerizations: polymer design by organic disulfides as iniferters," Die Makromolekulare Chemie, vol. 3, no. 2, pp. 127-132, 1982.

[46] J. P. Kennedy, "Functional polymers by cationic techniques," Journal of Macromolecular Science, vol. 13, no. 5, pp. 695-714, 1979.
[47] M. Szwarc and A. Rembaum, "Polymerization of methyl methacrylate initiated by an electron transfer to the monomer," Journal of Polymer Science, vol. 22, no. 100, pp. 189-191, 1956.

[48] M. Szwarc, M. Levy, and R. Milkovich, "Polymerization initiated by electron transfer to monomer. A new method of formation of block polymers," Journal of the American Chemical Society, vol. 78, no. 11, pp. 2656-2657, 1956.

[49] M. K. Georges, R. P. N. Veregin, G. K. Hamer, and P. M. Kazmaier, Macromolecular Symposia, vol. 88, p. 89, 1994.

[50] D. H. Solomon, E. Rizzardo, and P. Cacioli, "Polymerization process and polymers produced thereby," US patent no. 4581429, 1986.

[51] J. Krstina, G. Moad, E. Rizzardo, C. L. Winzor, C. T. Berge, and M. Fryd, "Narrow polydispersity block copolymers by freeradical polymerization in the presence of macromonomers," Macromolecules, vol. 28, no. 15, pp. 5381-5385, 1995.

[52] J.-S. Wang and K. Matyjaszewski, "Controlled "living" radical polymerization. Atom transfer radical polymerization in the presence of transition-metal complexes," Journal of the American Chemical Society, vol. 117, no. 20, pp. 5614-5615, 1995.

[53] K. Matyjaszewski, "Mechanistic and synthetic aspects of atom transfer radical polymerization," Journal of Macromolecular Science, vol. 34, no. 10, pp. 1785-1801, 1997.

[54] G. Kickelbick and K. Matyjaszewski, " $4,4^{\prime}, 4^{\prime \prime}$-tris(5-nonyl)$2,2^{\prime}: 6^{\prime}, 2^{\prime \prime}$-terpyridine as ligand in atom transfer radical polymerization (ATRP)," Macromolecular Rapid Communications, vol. 20, no. 6, pp. 341-346, 1999.

[55] B. Ivan, "Macromolecular nomenclature note no. 19: terminology and classification of quasiliving polymerizations and ideal living polymerizations on the basis of the logic of elementary polymerization reactions, and comments on using the term "controlled"," Macromolecular Chemistry and Physics, vol. 201, no. 17, pp. 2621-2628, 2000.

[56] T. R. Darling, T. P. Davis, M. Fryd, et al., "Living polymerization: rationale for uniform terminology," Journal of Polymer Science, vol. 38, no. 10, pp. 1706-1752, 2000. 

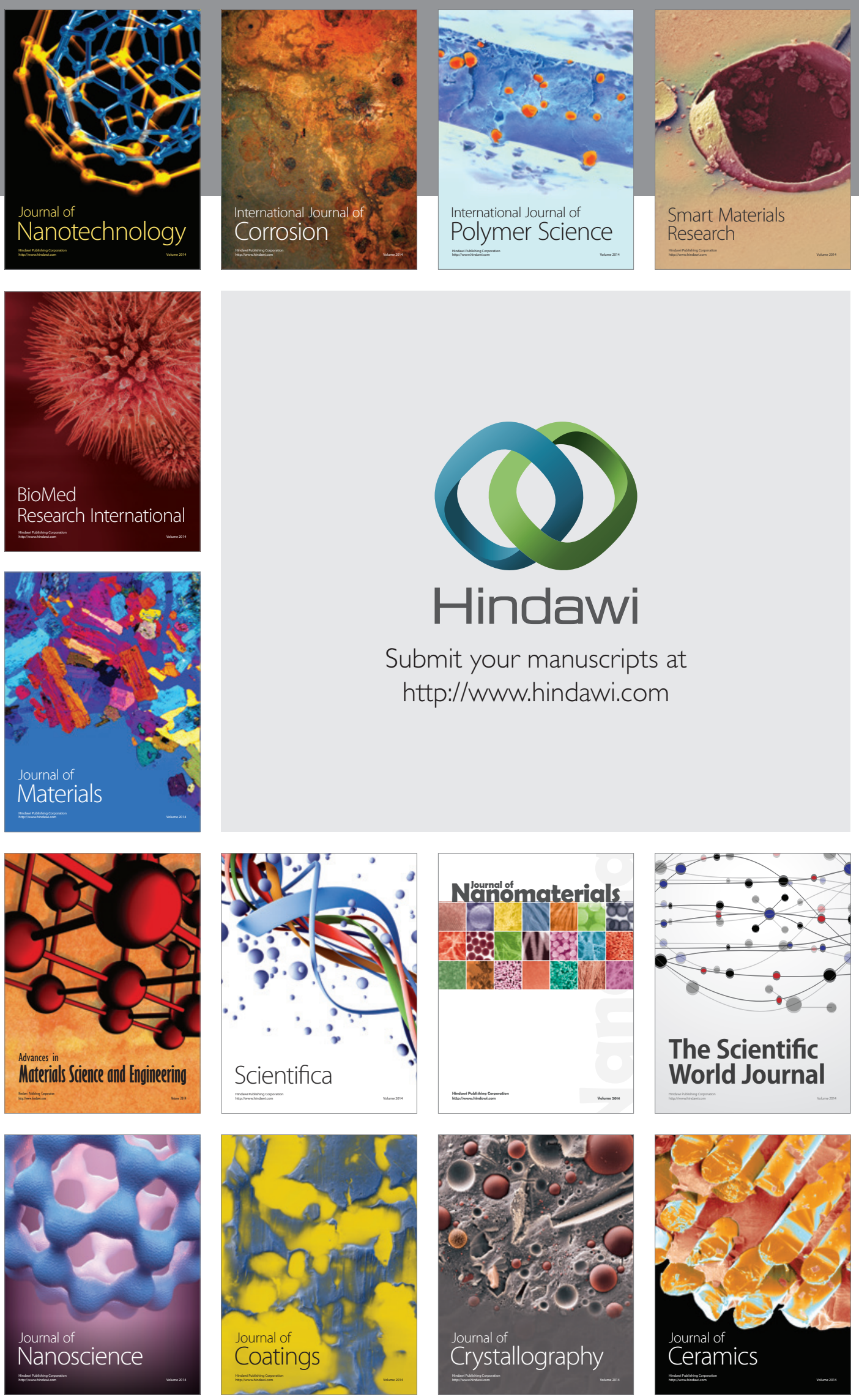

The Scientific World Journal

Submit your manuscripts at

http://www.hindawi.com

\section{World Journal}

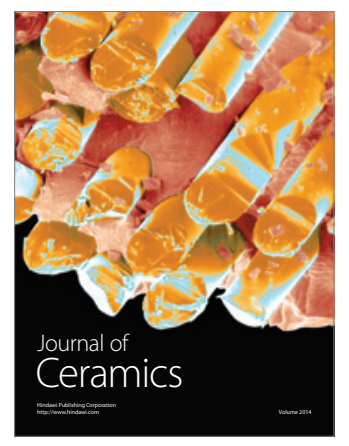

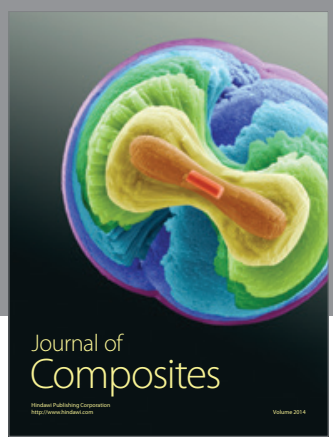
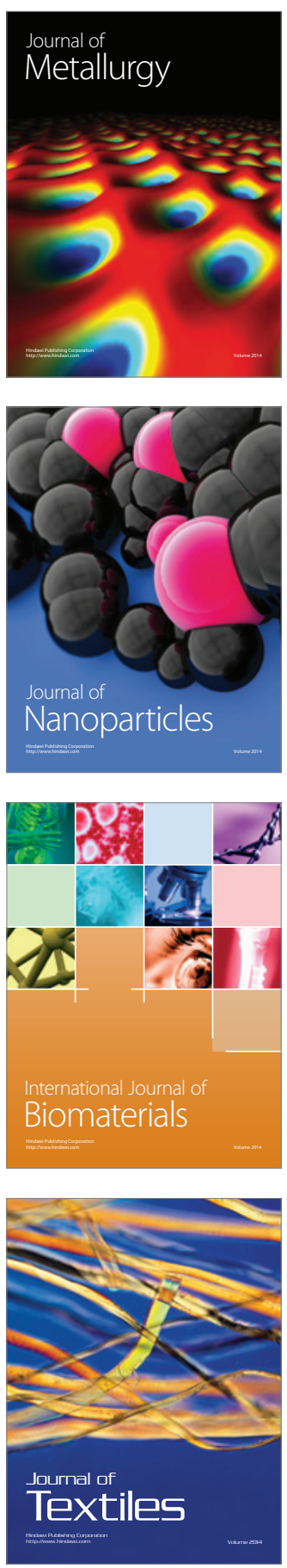